\title{
Origins and the Reasons of Monetary Crises in Georgia (1995-2016)
}

\author{
David Aslanishvili, Kristine Omadze² \\ ${ }^{1}$ Doctor of Economy, Faculty of Economy and Business, Tbilisi State University, Tbilisi, Georgia \\ ${ }^{2}$ Doctor of Business Administration, Tbilisi, Georgia \\ Email: d.aslanishvili@gmail.com,kristi.omadze@gmail.com
}

How to cite this paper: Aslanishvili, D. and Omadze, K. (2016) Origins and the Reasons of Monetary Crises in Georgia (1995-2016). Modern Economy, 7, 1232-1250.

http://dx.doi.org/10.4236/me.2016.711119

Received: September 6, 2016

Accepted: September 27, 2016

Published: September 30, 2016

Copyright $\odot 2016$ by authors and Scientific Research Publishing Inc. This work is licensed under the Creative Commons Attribution International License (CC BY 4.0).

http://creativecommons.org/licenses/by/4.0/

\begin{abstract}
The article "Monetary Crises in Georgia" (Authors: Doctor of Economy, David Aslanishvili and Doctor of Business Administration, Kristine Omadze) is the first attempt to overview the three main monetary crises in Georgian history since its independence and to study origins of the crises and evolution. The purpose of this article is to study the three monetary crises in Georgia itself and the errors in the Monetary Policy provided by The National Bank of Georgia and Georgian Government. It is crucial for stable economic development to have corrected Monetary Policy and to avoid mistakes similar to the mentioned in this article. At the same time, the article pays attention to importance of coordination providing Monetary Policy between the National Bank of Georgia and the Ministry of Finance. In our opinion only such coordination is the best solution for crisis prevention. Our research aims to determine the relevance and regularity of Georgian Lari (GEL) exchange rate and monetary policies conducted by the National Bank of Georgia.
\end{abstract}

\section{Keywords}

Currency Crisis, The Lari Exchange Rate, Monetary Aggregates, International Reserves, National Bank of Georgia

\section{Introduction}

National currency of Georgia-Lari (GEL) was emitted in September 1995. Its circulation was preceded by a stabilization program, which was enacted in 1994. Since then the circulation of the Lari money aggregates (M0, M1, M2 and foreign currency M3) in sequence, but is steadily increasing [1]-[3].

Our research studied the impact of monetary crisis on Georgian Lari (GEL) exchange 
rate against USD and the National Bank of Georgia's foreign exchange policy. In this regard, based on our study of the past twenty (20) years monetary policy, we have identified three major Georgian Lari currency crises [4]:

- 1998-1999 years, starting with Indonesia, moved into Russia and affected Georgian currency hardly-first currency crisis;

- 2008-2009 years-war conflict with Russia and global financial crisis-second currency crisis;

The first and the second monetary crises of Georgian Lari are observed based on historical performances, while the current one is ongoing issue and the study paid the special attention on it and its causes.

- 2014-2016 years-tightened monetary policy of Federal Reserve System of United States and strong US dollar-its influence on world currency system and Georgian case-the third and the most serious monetary and currency exchange crisis in Georgia.

Any article has the writing significance. In that point of view the theoretical and practical significance of this research is the following:

Since the restoration of independence, the main goal is to keep political and economic freedom and to improve it. In this regard, the cornerstone of economic policy should be based on the following direction - an independent and stable economic policy that will ensure the economic growth and welfare of the population and reliable integration Georgian into the world community as a successful, progress and innovation-oriented state.

In this regard, it is crucial to create solid and predictable environment inside the economy and monetary system that would be a reliable basis for further progress and development.

This model is called a strong asymmetry in financial industry. This is a model of financial system where every participant has the full access to the past information and analysis. Also, there is a transparent environment and reliable statistics to analyze the current events for correct prediction and, most importantly, there is an opportunity to plan for the future, expected financial strategy. Unfortunately, in Georgia we have fixed a weak form of asymmetry-there is available only past data. The luck of transparency of the current situation in the financial system, subjectivity, low level of financial and capital markets developments (and its actual de facto liquidation) creates reach conditions to have a system of oligopoly, where several groups manage the financial market due to its personal or emotional opinions, instead of free market.

Such system does not allow us to analyze the current situation and it is totally groundless to create any future forecasts and their possible reflection model. It removes the basis for any attempt to establish real stability and ensure sustainable of the future-oriented, long-term and stable development of the financial strategy.

In such circumstances, it is important for Georgia to study the past financial monetary crises, to gather data and to analyze it. The first attempt of such research is given in this paper. 


\section{Georgian Currency: The First Monetary Crisis of 1998-1999}

It should be noticed that the starting position of Georgian Lari monetary aggregates since introduction can be characterized by the following parameters: At the end of October 1995, the Georgian Lari monetary aggregate (M2) was equal to 112.3 million GEL [5]. At the same time, the entire supply of the Georgian banking system's by the foreign currency (M3 minus M2) was 19 million Georgian lari, or it was equal to 15 million USD due to the fixed exchange rate of US dollar to Georgian Lari (US $\$ 1=1.3 \mathrm{GEL}$ ) at the end of October 1995. This fixed exchange rate of US dollar to Georgian Lari lasted until 1998. At the end of 1997 Georgian Lari (GEL) monetary aggregate (M2) reached 295 million Lari, while the foreign currency at banking system (M3 minus M2) was equal to 75.5 million GEL, or 58 million USD [5]. In 1998, the National Bank of Georgia announced the new era in currency rates-it shifted to a floating exchange rate and the end of August 1998, the situation was as follows [1]:

- Georgian Lari monetary aggregate (M2) - was equal to 294 million. Lari (i.e. unchanged with data for December 1997);

- Foreign currency at the banking system (M3 minus M2) - was 100.5 million Gel or 80 million US dollar (actual exchange rate was 1 US dollar $=1.35$ Georgian lari).

At the same time, Georgia's international currency reserves had the following structure:

As Table 1 and Table 2 and the official data presents, foreign exchange reserves are more or less stable, and there is a numerical change in this period due to a number of international contracts expiration, or debt coverage and another debts to fill the reserve tranche.

In September 1998, the foreign exchange market in Georgia was badly affected by financial crisis, starting in Indonesia and moved to Georgia from Russia. Actually, Georgia was kind of a victim of this regional crisis due to its close economic ties to Russia. At the same time, this event have shown that neither the Government nor the National Bank of Georgia were prepared for the crisis [6].

Table 1. Monetary aggregates of Georgian Lari (1995-1998).

\begin{tabular}{ccccc}
\hline Year, month & $\begin{array}{c}\text { Money } \\
\text { aggregates (M3), } \\
\text { thous. of GEL }\end{array}$ & $\begin{array}{c}\text { Money } \\
\text { aggregates (M2), } \\
\text { thous. of GEL }\end{array}$ & $\begin{array}{c}\text { Money } \\
\text { aggregates (M1), } \\
\text { thous. of GEL }\end{array}$ & $\begin{array}{c}\text { Money outside } \\
\text { banks (M0), } \\
\text { thous. of GEL }\end{array}$ \\
\hline October-1995 & 131,419 & 112,337 & 107,279 & 84,708 \\
December-1995 & 179,441 & 160,145 & 154,534 & 124,779 \\
June-1996 & 200,404 & 173,516 & 166,869 & 130,458 \\
December-1996 & 255,754 & 220,751 & 212,448 & 176,733 \\
June-1997 & 262,436 & 215,412 & 202,166 & 168,531 \\
December-1997 & 370,497 & 294,974 & 277,863 & 239,691 \\
June-1998 & 379,560 & 281,441 & 265,401 & 220,694 \\
August-1998 & 394,825 & 294,175 & 279,633 & 230,411 \\
\hline
\end{tabular}

Source: National Bank of Georgia https://www.nbg.gov.ge/index.php?m=304. 
Table 2. International currency reserves (1995-1998).

\begin{tabular}{cc}
\hline Year, month & Official foreign currency reservces (in thousand USD) \\
\hline 31.10 .1995 & $171,261.9$ \\
31.12 .1995 & $196,188.8$ \\
30.06 .1996 & $193,571.9$ \\
31.12 .1996 & $190,850.2$ \\
30.06 .1997 & $129,001.5$ \\
31.12 .1997 & $200,445.9$ \\
30.06 .1998 & $138,861.5$ \\
31.07 .1998 & $122,746.4$ \\
31.08 .1998 & $163,966.0$ \\
\hline
\end{tabular}

Source: National Bank of Georgia https://www.nbg.gov.ge/index.php?m=304.

We analyzed the most acute phase of the crisis-October 1998-March 1999. From the outset, we note that the depreciation of Georgian Lari against US dollar was a very strong one and it dropped officially from the rate of US \$1 - 1.35 Georgian lari to 1 US dollar $=2.45$ Georgian lari, or Georgian currency sufferred 82 percent devaluation rate. However, according to our information, depreciation at unofficial market (currency exchange in the streets) was even more dramatic, and in late November and early December of 1998, it approached the level of US \$ $1=3$ GEL [1] [7].

This crisis affected monetary aggregates and statistical figures were the following (Table 3).

As we see, in the most critical period (November, 1998) - monetary aggregate (M2fell down to 207 million Lari, or decreased by 87 million (or 30 percent), while the foreign currency at banking system (M3 minus M2) decreased by 100 million Gel and dropped to 55 million US dollars (decreased by 32 percent) [1].

Such Financial deterioration was accompanied with sharp rise in the interest rate on the government securities market (it reached 60 per cent annual rates), most of emissions were not fulfilled at all and lately emission of Georgian Tbills were stopped. During the winter of 1999, we have fixed Lari emission, sequester the State budget and lately, the currency rate stabilized at $2.2-2.45$ Gel frames to 1 USD [8].

It should be noted negative impact of such crisis on Georgian international reserves level (Table 4).

The official data shows, the National Bank of Georgia used its foreign currency reserves and intervened market to prevent Lari depreciation. As the result of it-three times the foreign exchange reserves in 1998 and 1999 reached its historical minimum97 million US dollars [5].

In 1999, The National Bank of Georgia had agreed to provide its currency policy in line with IMF and World Bank recommendations and it had received a loan from the IMF and filled foreign exchange reserves up to 234 million US dollars. But lately, this sum was used for new interventions, debt were covered and foreign reserves lost its half from this amount. 
Table 3. Monetary aggregates of Georgian Lari (1998-1999).

\begin{tabular}{ccccc}
\hline Year, month & $\begin{array}{c}\text { Money aggregates } \\
(\text { M3), thous. of GEL }\end{array}$ & $\begin{array}{c}\text { Money aggregates } \\
(\text { M2), thous. of GEL }\end{array}$ & $\begin{array}{c}\text { Money aggregates } \\
(\mathrm{M} 1) \text {, thous. of GEL }\end{array}$ & $\begin{array}{c}\text { Money outside } \\
\text { banks (M0), } \\
\text { thous. of GEL }\end{array}$ \\
\hline October-1998 & 320,862 & 228,571 & 216,067 & 183,579 \\
November-1998 & 295,186 & 207,171 & 196,161 & 168,784 \\
December-1998 & 364,963 & 259,865 & 250,296 & 212,185 \\
January-1999 & 402,252 & 273,806 & 264,325 & 226,875 \\
February-1999 & 416,203 & 264,952 & 254,164 & 220,651 \\
March-1999 & 398,962 & 251,628 & 241,743 & 206,901 \\
\hline
\end{tabular}

Source: National Bank of Georgia https://www.nbg.gov.ge/index.php?m=304.

Table 4. International currency reserves (1998-1999).

\begin{tabular}{cc}
\hline Year, month & Official foreign currency reservces (in thousand USD) \\
\hline 30.09 .1998 & $132,161.4$ \\
31.10 .1998 & $118,850.4$ \\
30.11 .1998 & $97,659.1$ \\
31.12 .1998 & $127,792.5$ \\
31.01 .1999 & $234,464.8$ \\
28.02 .1999 & $118,013.0$ \\
31.03 .1999 & $108,817.5$ \\
30.04 .1999 & $103,569.0$ \\
31.05 .1999 & $101,453.6$ \\
30.06 .1999 & $97,360.4$ \\
31.07 .1999 & $97,570.3$ \\
\hline
\end{tabular}

Source: National Bank of Georgia https://www.nbg.gov.ge/index.php?m=304.

In this regard, to overcome the most acute phase of currency crisis in 1998-1999, the National Bank spent 100 - 110 million US dollars (own calculations of the reserve reduction, banks currency outflow and interventions analyzing data) in 1998. In addition, The NBG spent $50 \mathrm{mln}$. USD in 1999, to stabilize currency rate (own calculations of the reserve to reduce the outflow of currency from the banks and interventions based on the analysis of the data). Totally, price of first crisis can be calculated as 150 million USD [1].

\section{Monetary Policy between the First and the Second Monetary Crisis (2003-2008)}

Time, followed the first monetary crisis of 1998-1999, can be classified as the period of stabilization of exchange rate, growth confidence to Georgian Lari, that resulted Lari deposits quick (short and long-term time deposits) increased. Due to our study, it seems there is a wide difference in reasons and tools between the first and the second 
crisis. The first one was resulted as the echo of Russian financial crisis of 1998 and it influenced Georgia as it was the economically dependent state on Russia. Weak Georgian financial system, luck of trustee to national currency and absence of independent financial policy results its harsh results. The first crisis was overcome thanks to little size of Larimonetary aggregates in circulation, loans from World Bank and the IMF and less involvement of the State into economy (especially on its late period in 1999). The Second crisis was resulted by both domestic mistakes in monetary policy and force majeure situation-August War with Russian Federation. Mostly the second crisis was overcome by the international donor's assistance, rather than domestic policy and monetary tools. We have studied in details the period between the first and the second crisis:

Monetary aggregates also showed tendency to grow. Launched in 2004 a large-scale privatization program added confidence to Georgian Lari and sharp increase in foreign investment strengthened Lari exchange rate. Level of foreign reserves was rapidly increasing too. If we follow the official figures, at the end of 2003, Georgia's international reserves was not even 200 million US dollars, but in 2004 it reached 386 million US dollars and 930 millionUSD in 2006 [9] (Table 5).

At the same time, monetary aggregates had the following tendency (Table 6).

At the end of 2003, monetary aggregate (M2) exceeded 530 millionGel, while the foreign currency supply (M3 minus M2) was 565 million Gel or 280 million US dollars as of exchange rate at the end of December 2003 (1 US dollar = 2075 GEL).

Table 5. International currency reserves (2001-2006).

\begin{tabular}{|c|c|c|c|c|c|}
\hline Official reserve assets & & & Year & & \\
\hline $\begin{array}{c}\text { and other assets in } \\
\text { foreign currency }\end{array}$ & 2001 & 2003 & 2004 & 2005 & 2006 \\
\hline (mln USD) & 117.4 & 196.2 & 386.6 & 478.6 & 930.8 \\
\hline
\end{tabular}

Source: National Bank of Georgia https://www.nbg.gov.ge/index.php?m=304.

Table 6. Monetary aggregates of Georgian Lari (1999-2003).

\begin{tabular}{ccccc}
\hline Year, month & $\begin{array}{c}\text { Money } \\
\text { aggregates (M3), } \\
\text { thous. of GEL }\end{array}$ & $\begin{array}{c}\text { Money } \\
\text { aggregates (M2), } \\
\text { thous. of GEL }\end{array}$ & $\begin{array}{c}\text { Money } \\
\text { aggregates (M1), } \\
\text { thous. of GEL }\end{array}$ & $\begin{array}{c}\text { Money outside } \\
\text { banks (M0), } \\
\text { thous. of gel }\end{array}$ \\
\hline April-1999 & 389,811 & 254,674 & 246,858 & 212,913 \\
December-1999 & 435,668 & 282,713 & 274,879 & 244,038 \\
December-2000 & 608,119 & 380,271 & 369,644 & 315,205 \\
June-2001 & 645,210 & 359,697 & 350,171 & 296,047 \\
December-2001 & 749,331 & 405,377 & 395,632 & 348,850 \\
June-2002 & 784,325 & 403,024 & 392,050 & 341,273 \\
December-2002 & 890,308 & 465,096 & 454,844 & 390,791 \\
June-2003 & 955,824 & 453,456 & 443,960 & 374,885 \\
December-2003 & $1,095,628$ & 530,277 & 519,380 & 441,536 \\
\hline
\end{tabular}

Source: National Bank of Georgia https://www.nbg.gov.ge/index.php?m=304. 
Accordingly, in December 2003, the foreign exchange currency at banking system in Georgia exceeded its minimum level of the first crisis summit at November 1998, 5 times (500 percent growth), while the Georgian Lari monetary aggregate (M2) in circulation in the same period of time increased from 207 million Gel to 530 million Gel, or just 2.5 times growth (250 percent). It shows that:

- Trust toward Georgian Lari was much smaller than to US dollar;

- Lari saving function does not actually possessed;

- The financial system and money aggregates were mostly stabilized by foreign currency inflow in country.

Since 1999, exchange rate of Georgian Lari against the US dollar had showed strong tendency to appreciate. It should be noticed-the National Bank of Georgia (the NBG) was reluctant to sell US dollars in the period of late 1999 up to January 2004. Only in 2004, the NBG had started bilateral interventions (i.e. the purchase and sale of foreign currency). This stable situation reflected exchange rate and it increased from 2.12 Georgian lari per 1 US dollar to 1995 Gel per 1 USD.

Second half of 2004 and further period can be described as the foreign currency inflow time in Georgia (Mass privatization, strong economy growth) and in this regard, the National Bank acts as foreign currency purchaser (mostly USD) and supplier of Lari monetary units to economy. As a result of such policy, at the end of 2004, Lari appreciate against to USD and reached 1.8 Georgian Lari per 1 USD. This exchange rate, with little volatility (in the frame of 1.8 - 1.9 Gel per USD), was maintained in 2005 [10].

At the end of 2005 (Table 7), the official statistics showed: monetary aggregate (M2) reached 1104 million Georgian lari (539 million Gel increase in compare to 2003 figure), while the foreign currency amount (M3 minus M2) at banking channels was 857 million lari, or 480 million US dollars (200 million USD increase as compared to 2003) [5].

It was clear sign that Georgian economy and monetary aggregates growth in terms of volume. It was coupled with simultaneous increase in foreign exchange reserves at a rapid pace. In our opinion, 2006-2007 period was a tailrace one, as for foreign exchange policy. It determined an unintended or deliberate errors of the next period.The first quarter of 2006 was unremarkable one and similar to the pervious one's, but in the second quarter there was a large amount (flow) of foreign currency on the market, which was purchased by he National Bank and therefore an enourmous increase of Georgian Lari monetary aggregate took place [1].

In Spring and in Autumn of 2006, the National Bank of Georgia bought 350 million US dollars, but the exchange rate of Lari had changed a little and it was in $1.85-1.73$ Gel framework against 1 USD.Over the next 10 months of 2007, the National Bank of Georgia bought the record amount of foreign currency in its history-755 million US dollars and again supplied market with Georgian Lari monetary aggregates. Due to such a large-scale purchases, the Georgian Lari continued its strengthening against USD and reached exchange rate $1 \mathrm{USD}=1.62 \mathrm{Gel}$ at the end of October, 2007. 
Table 7. Monetary aggregates of georgian lari (2004-2005).

\begin{tabular}{ccccc}
\hline Year, month & $\begin{array}{c}\text { Money } \\
\text { aggregates (M3), } \\
\text { thous. of GEL }\end{array}$ & $\begin{array}{c}\text { Money } \\
\text { aggregates (M2), th- } \\
\text { ous. of GEL }\end{array}$ & $\begin{array}{c}\text { Money } \\
\text { aggregates (M1), } \\
\text { thous. of GEL }\end{array}$ & $\begin{array}{c}\text { Money outside } \\
\text { banks (M0), } \\
\text { thous. of GEL }\end{array}$ \\
\hline January-2004 & $1,091,371$ & 515,978 & 504,200 & 416,333 \\
July-2004 & $1,263,946$ & 632,364 & 616,819 & 477,710 \\
December-2004 & $1,534,208$ & 856,521 & 827,750 & 615,993 \\
June-2005 & $1,671,232$ & 910,986 & 874,191 & 636,495 \\
December-2005 & $1,961,505$ & $1,104,130$ & $1,029,383$ & 736,284 \\
\hline
\end{tabular}

Source: National Bank of Georgia https://www.nbg.gov.ge/index.php?m=304.

In our view, October 2007 can be described as the end of the existed exchange rate policy and the new cycle was launched. In that field, it is usefull to look at Georgian Lari monetary aggregate and foreign exchange reserves at first, before to overview the next monetary cycle. Especially, we have noticed the sharp increase of monetary aggregates, which were carried out during this period (Table 8).

As the data for 2005-2006 reveals, monetary aggregate (M2) increased by 369 million Gel, while foreign currency inflows in the banking channels was much higher-838 million Gel, which is exceeded by 488 million USD (at a rate of 1 USD $=1.715 \mathrm{Gel}$ ) the previous year's result. Totally, the amount of foreign currency in banking system amounted to 1.326 million Gel, which was equal to 773 million US dollars.

Growth tendency was fixed in 2007 too. At the end of 2007, the monetary aggregate M2 reached 2. 262 million Gel. During the same period the volume of foreign currency in banks reached 1835 million GEL, which was equal to 1.153 million US dollars (1 US dollar $=1.5915$ GEL rate) or 380 million USD more, compare to the previous 2006 year result [1].

In November 2007 (Table 9), the Demonstrations and lately early presidential elections had an impact on monetary policy, and in November and December, there were foreign exchange interventions from NBG. Due to that, the foreign exchange reserve (1.510 million US dollars in October, 2007) was lowered and, at the end of 2007, it was equal to 1.361 million US dollars. However, the NBG introduced an artificial exchange rate and we can conclude that foreign exchange rate was determined by political will, rather than by market mechanisms.

The first half of the 2008 was leaded by election cycle the unstable situation was remained. To ease situation, the government of Georgia have issued euro bonds on 500 million USD and this debt haveincreased the volume of foreign exchange reservesin April 2008, but later this amount was spent on currency intervention to keep the "politically comfortable" exchange rate [11] [12].

On the break of "August War in 2008" with Russia, the monetary and currency system had the following standing:Monetary aggregate (M2) was equal to 2.710 million Gel or 450 million Gel more than in late 2007; foreign currency amount at banking channels was equal to 1.815 million Gel, or 20 million less than in late 2007. In US 
Table 8. Monetary aggregates of Georgian Lari (2006-2008).

\begin{tabular}{ccccc}
\hline Year, month & $\begin{array}{c}\text { Money } \\
\text { aggregates (M3), } \\
\text { thous. of GEL }\end{array}$ & $\begin{array}{c}\text { Money } \\
\text { aggregates (M2), } \\
\text { thous. of GEL }\end{array}$ & $\begin{array}{c}\text { Money } \\
\text { aggregates (M1), } \\
\text { thous. of GEL }\end{array}$ & $\begin{array}{c}\text { Money outside } \\
\text { banks (M0), } \\
\text { thous. of GEL }\end{array}$ \\
\hline December-2006 & $2,799,780$ & $1,473,169$ & $1,337,737$ & 827,357 \\
June-2007 & $3,374,828$ & $1,744,971$ & $1,556,075$ & 851,145 \\
December-2007 & $4,098,857$ & $2,262,963$ & $1,947,554$ & $1,152,070$ \\
June-2008 & $4,341,414$ & $2,573,610$ & $2,137,886$ & $1,235,407$ \\
July-2008 & $4,525,406$ & $2,710,358$ & $2,238,727$ & $1,290,945$ \\
\hline
\end{tabular}

Source: National Bank of Georgia https://www.nbg.gov.ge/index.php?m=304.

Table 9. International currency reserves (2006-August, 2008).

\begin{tabular}{|c|c|c|c|c|c|c|}
\hline \multirow{3}{*}{$\begin{array}{l}\text { Official reserve assets } \\
\text { and other assets in } \\
\text { foreign currency } \\
\text { (mln USD) }\end{array}$} & \multicolumn{6}{|c|}{ YEAR } \\
\hline & 2006 & 2007 (October) & 2007 & 2008 (April) & 2008 (May) & 2008 (August) \\
\hline & 930.8 & 1510.4 & 1361.1 & 1910.3 & 1497.6 & 1122.9 \\
\hline
\end{tabular}

Source: National Bank of Georgia https://www.nbg.gov.ge/index.php?m=304.

dollar, it means 37 million USD less amount of foreign currency was at banking channels in compare to end of 2007 (or 1.289 million US dollars) [1] [5].

That was a direct sign that Georgia had the negative trend of flow of foreign currency at banking channels and it looks especially strange the fact that the Georgian Lari continued appreciation against USD and reached the rate $1 \mathrm{USD}=1397 \mathrm{Gel}$. It was a clear indication of administrative pressure on currency exchange rate [1].

We can state-further strengthen the exchange rate of Lari against US Dollar from November 2007 up to August 2008 was of artificial nature and did not reflect the real situation.

At the same time, there has been high inflation, which exceeded the target figure. These factors have prompted the central bank to increase the refinancing rate up to 12 percent annually. As the result the lending rate of commercial bank loans soared from 13 percent to 30 percent annually [10].

\section{Georgian Currency: The Second Monetary Crisis of 2008-2009 (August War of 2008 and Global Financial Crisis)}

The "August war of 2008" and the global financial crisis had sharp and negative influence on Georgia. Especially it was difficult to overcome the new challenges in the face of existed problems of the financial system in Georgia. Thanks to generous support from World Community (4.5 billion USD had been allocated for Georgia as post-war country in 2008) and loans from International Monetary Fund (1.3 billion USD) most challenges in economy were actually "poured by money" and its influence was largely neutralized, but some negative events and challenges, badly affected Georgian Lari stability—its saving and depository function had been ruined [13] [14]. 
Most clearly the impact of the war and the crisis in terms of monetary aggregates is demonstrated in the Table 10.

The official data shows:In the time frame from July 2008-March 2009, monetary aggregate M2aggregate decreased from 2.710 million Gel to 1.778 million GEL, or it lost almost 1 billion GEL. Actually, it was equal to 37 percent of M2 aggregate. Such decrease and economy slowdown followed by a deep stagnation and negative economic growth that faced Georgia in Late 2008 and in 2009 [15].

What is most strange, until November 2008, despite the war, military aggression and the crisis, Georgian lari exchange rate was fixed and stable at the rate of 1 USD-1.4 Gel. Suddenly, in November 2008, just in a few days exchange rate was "depreciated" to $1 \mathrm{USD}=1.65$ Gel [14] [16].

It should be noted that this exchange rate, with more or less weak fluctuation in the range of 1.6 - 1.8 Gel per 1 USD was maintained until the end of 2013.

Obviously, all of these actions were accompanied by the large-scale foreign exchange interventions, the net volume of which amounted to 875 million US dollarsin the period of July 2008 to March 2009 [17].

Such a large-scale foreign exchange spending was not influenced the official figures of international reserves due to of donors' grants and debts ( 4.5 billion USD program) and World Bank support (up 1.1 billion USD). With such a massive support, official figures of Georgian foreign reserves showed tendency to grow (Table 11).

Table 10. Monetary aggregates of georgian lari (2008-March, 2009).

\begin{tabular}{ccccc}
\hline & $\begin{array}{c}\text { Money } \\
\text { aggregates (M3), } \\
\text { thous. of GEL }\end{array}$ & $\begin{array}{c}\text { Money } \\
\text { aggregates (M2), } \\
\text { thous. of GEL }\end{array}$ & $\begin{array}{c}\text { Money } \\
\text { aggregates (M1), } \\
\text { thous. of GEL }\end{array}$ & $\begin{array}{c}\text { Money outside } \\
\text { banks (M0), } \\
\text { thous. of GEL }\end{array}$ \\
\hline August-2008 & $4,014,688$ & $2,421,845$ & $2,066,256$ & $1,245,779$ \\
September-2008 & $4,089,682$ & $2,405,603$ & $2,045,450$ & $1,196,489$ \\
October-2008 & $4,009,512$ & $2,301,163$ & $1,947,641$ & $1,154,045$ \\
November-2008 & $4,062,943$ & $2,070,356$ & $1,779,908$ & $1,059,340$ \\
December-2008 & $4,421,698$ & $1,999,220$ & $1,752,459$ & $1,082,554$ \\
January-2009 & $4,146,756$ & $1,862,990$ & $1,641,025$ & 991,498 \\
February-2009 & $4,035,788$ & $1,803,649$ & $1,589,466$ & 961,048 \\
March-2009 & $3,815,625$ & $1,778,077$ & $1,573,465$ & 960,173 \\
\hline
\end{tabular}

Source: National Bank of Georgia https://www.nbg.gov.ge/index.php?m=304.

Table 11. International currency reserves (2008-2009).

\begin{tabular}{|c|c|c|c|c|}
\hline \multirow{3}{*}{$\begin{array}{c}\text { Official reserve assets } \\
\text { and other assets in } \\
\text { foreign currency (mln USD) }\end{array}$} & \multicolumn{4}{|c|}{ Year } \\
\hline & \multirow{2}{*}{2008} & 2009 & 2009 & 2009 \\
\hline & & June & October & December \\
\hline & 1480.2 & 1518.2 & 2030.5 & 2110.4 \\
\hline
\end{tabular}

Source: National Bank of Georgia https://www.nbg.gov.ge/index.php?m=304. 
At the same time, we should state-monetary policy of 2008 and 2009 was not in line with elementary market economy principles and massive intervention and spending of foreign currency from reserves did not support to transform economy. Actually, resources were wasted with no purposes. Thus, it was retained the inappropriate economic system and economic ties, which were not in line with the development and were far from competitiveness-oriented economy. All these problems appeared together at the end of 2014, when donor money dried up and a large-scale currency crisis was launched and now reigns in Georgia [1].

\section{Georgian Monetary Policy between the Second and the Third Currency Crisis (2009-2013)}

Before to discuss the period between the second and the third crisis, we would like to outline the differences and common points in monetary policy resulted it. The time between the $2^{\text {nd }}$ and the $3^{\text {rd }}$ crisis has in fact differences between the tools used by the National Bank of Georgia. The third crisis was actually stimulated by the internal debt growth and, lately, it's refinancing by the National Bank of Georgia. It results Lari monetary aggregates increase from $4 \mathrm{mlrd}$ Gel to $5.9 \mathrm{mlrd}$ Gel. In conditions of tightened monetary policy provided by Federal Reserve System of United States from October 2014 and strong US dollar, it hardly influenced Georgian currency and Lari lost its saving function. Lari depreciated by 44 percent against USD and this crisis was the most serious monetary and currency exchange crisis in Georgia. We have studied in details the period between the second and the third crisis: Four years of post-war period can be described as stability and "stagnation" era together-the Government and the National Bank of Georgia successfully "appropriated" 4.5 billion US dollars of donor's contribution and no actions were implemented to reform the economy and to improve (shortening) the deficit of export/import structure.

In this period of seeming stability, Lari monetary aggregate and foreign currency flow at banking channels were stable and had tendency to grow (Table 12).

Table 12. Monetary aggregates of Georgian Lari (April, 2009-December, 2013).

\begin{tabular}{cccc}
\hline $\begin{array}{c}\text { Money } \\
\text { aggregates (M3), } \\
\text { thous. of GEL }\end{array}$ & $\begin{array}{c}\text { Money } \\
\text { aggregates (M2), } \\
\text { thous. of GEL }\end{array}$ & $\begin{array}{c}\text { Money } \\
\text { aggregates (M1) } \\
\text { thous. of GEL }\end{array}$ & $\begin{array}{c}\text { Money outside } \\
\text { banks (M0), } \\
\text { thous. of GEL } \\
3,637,932\end{array}$ \\
$\begin{array}{c}1,816,818 \\
1,922,696\end{array}$ & $1,959,227$ & $1,633,306$ & $1,005,005$ \\
$4,763,607$ & $2,330,486$ & $2,019,366$ & $1,075,848$ \\
$5,154,387$ & $2,537,542$ & $2,219,909$ & $1,229,436$ \\
$6,199,009$ & $2,960,254$ & $2,509,999$ & $1,269,456$ \\
$6,164,201$ & $2,939,244$ & $2,418,582$ & $1,372,989$ \\
$7,097,777$ & $3,783,180$ & $3,137,907$ & $1,248,893$ \\
$7,242,927$ & $3,686,240$ & $3,011,487$ & $1,438,992$ \\
$7,903,739$ & $4,069,162$ & $3,336,948$ & $1,344,033$ \\
$8,354,699$ & $4,349,611$ & $3,392,516$ & $1,550,028$ \\
$9,836,619$ & $5,418,403$ & $4,307,502$ & $1,489,096$ \\
\hline
\end{tabular}

Source: National Bank of Georgia https://www.nbg.gov.ge/index.php?m=304. 
Monetary aggregate M2 increased from 1.816 million (in April 2009) up to 4,069 mln to the late of 2012. But most alarming was the period from June 2013 to December 2013, when monetary aggregate 4349 million Gel reached 5.418 million Gel just in six months -1.070 million lari, which led to a sharp fall in the exchange rate against the US dollar (from 1.65 Gel to 1.75 Gel against 1 USD) [5].

It should be noted that foreign currency and mostly US dollar flows at banking channels in Georgia had a very good positive trend:

- In December 2012, there were 7.903 million Gel of monetary aggregate of M3 in circulation. Difference of M3 and M2 was equal to 2.300 million US dollars, based on actual year-end exchange rate ( $1 \mathrm{USD}=16,567 \mathrm{GEL}$ );

- In December 2013, M3 monetary aggregate reached 9.837 million Gel or 2.545 million USD at banking channels (Difference between M3 and M2). Exchange rate was $1 \mathrm{USD}=1.7363 \mathrm{Gel}$.

In order to stabilize the exchange rate of Georgian Lari, the National Bank spent part of international reserves and the level of reserves decreased from the record 3.110 million USD in October 2013 to 2.823 million USD at the end of 2013 (just in two months) [1] [18].

It should be noted that similar errors and non-coordinated activity were continued lately and it had particularly negative role during the last currency crisis, started in the fall of 2014 and still raging in Georgia (Table 13).

\section{Georgian Currency: The Third Monetary Crisis of 2014-2016}

During 2014-2016 tightened monetary policy provided by Federal Reserve System of United States and strong US dollar hardly influenced world currency system and Georgian as part of it. It was the third and the most serious monetary and currency exchange crisis in Georgia. At the end of 2014, the US Federal Reserve Bank officially announced the end of "quantitative easing policy" and as result of it, the US dollar strengthened against all major currencies. This issue affected global economy, slowdown global growth; resulted sharp drop in energy prices and further expectations of global markets and currencies just triggered sharp volatility. In this regard, Georgian foreign exchange market, which faced luck of liquidity and market principles in its structure was unprepared for this challenge and suffered hardly [19].

This situation was compounded with money aggregate growth, which (M 2 level) reached 5.911 million Gel in December 2014 (1 billion or 20 percent increase of money supply only in 2014). That was one of the main reasons of Georgian currency crisis and

Table 13. International currency reserves (2010-2013).

\begin{tabular}{ccccccc}
\hline & \multicolumn{7}{c}{ Year } \\
\cline { 2 - 7 } $\begin{array}{c}\text { Official reserve assets } \\
\text { and other assets in } \\
\text { foreign currency (mln USD) }\end{array}$ & 2010 & 2011 & 2012 & 2012 & 2013 & 2013 \\
\cline { 2 - 7 } & XII & XII & VIII & XII & X & XII \\
\cline { 2 - 7 } & 2263.9 & 2818.3 & 2943.7 & 2873 & 3110.1 & 2823.4 \\
\hline
\end{tabular}

Source: National Bank of Georgia https://www.nbg.gov.ge/index.php?m=304. 
its depreciation. As a result, the exchange rate depreciated against the US dollar from 1.7363 (December 2013) up to 2.4985 (28 January 2016) (44 percent devaluation) [20].

It is worthwhile to consider the situation regarding foreign currency flow at Georgian banking system:

- 2.383 million USD was the total volume of foreign currency at banking channels (M3 minus M2) at the end of 2014;

- 3.155 million USD was the total volume of foreign currency at banking channels (M3 minus M2) at the end of 2015.

However, in January 2016, this volume decreased to 3.107 million US dollars. At the same time, the pace of growth of foreign currency at banking channels was sharply lower than the growth of Georgian Lari monetary aggregates. That was an additional negative factor in line with other challenges coming from global markets. These circumstances affected Georgian currency market and decline of Georgian Lari exchange rate against US dollar was inevitable.

Georgia's International currency reserves revealed the unfavorable trend. In October 2013, the foreign currency reserves reached its historical maximum of 3.110 million US dollars, but it was reduced to 2.447 million US dollars as of January 2016, (21 percent shortage) (Table 14). At the same time, such intervention did not decrease the Georgian Lari monetary aggregates in circulation. At the end of the 2013 there were 5.418 million Georgian Lari (M 2) and in January 2016 it was equal to 5,403 million (M 2) [21].

In fact, 663 million US dollars from foreign reserves were spent generously and without any definite purpose [22] [23].

As we concluded, the growth of the monetary aggregates in Georgian Lari was not supported by foreign currency inflow and that was the reason of exchange rates sharp fluctuation. Based on our study, broad money aggregates high growth rate in 2012-2015 years was directly linked to the Political decision of Georgian government to support domestic production based on internal debt growth (Table 15). This will and other numerous political promises were given during the election in 2012 and were lately executed by the Government of Georgia, Ministry of Finance and the National Bank of

Table 14. Monetary aggregates of georgian lari (2014-January, 2016).

\begin{tabular}{ccccc}
\hline Year, month & $\begin{array}{c}\text { Money } \\
\text { aggregates (M3), } \\
\text { thous. of GEL }\end{array}$ & $\begin{array}{c}\text { Money } \\
\text { aggregates (M2), } \\
\text { thous. of GEL }\end{array}$ & $\begin{array}{c}\text { Money } \\
\text { aggregates (M1), } \\
\text { thous. of GEL }\end{array}$ & $\begin{array}{c}\text { Money outside } \\
\text { banks (M0), } \\
\text { thous. of GEL }\end{array}$ \\
\hline January-2014 & $9,453,973$ & $4,910,384$ & $3,800,826$ & $1,725,649$ \\
June-2014 & $10,130,909$ & $5,208,363$ & $3,995,785$ & $1,815,070$ \\
December-2014 & $11,189,836$ & $5,911,310$ & $4,460,837$ & $1,942,582$ \\
June-2015 & $11,792,213$ & $5,658,530$ & $4,168,497$ & $1,979,812$ \\
December-2015 & $13,343,921$ & $5,762,932$ & $4,435,599$ & $1,981,936$ \\
January-2016 & $13,172,033$ & $5,403,938$ & $4,114,187$ & $1,825,973$ \\
\hline
\end{tabular}

Source: National Bank of Georgia https://www.nbg.gov.ge/index.php?m=304. 
Table 15. International currency reserves (2014-January, 2016).

\begin{tabular}{cccc}
\hline & \multicolumn{3}{c}{ Year, month } \\
\cline { 2 - 4 } $\begin{array}{c}\text { Official reserve assets and } \\
\text { other assets in foreign } \\
\text { currency (mln USD) }\end{array}$ & 2014 & 2015 & 2016 \\
\cline { 2 - 4 } & XII & XII & 1 \\
\hline
\end{tabular}

Source: National Bank of Georgia https://www.nbg.gov.ge/index.php?m=304.

Georgia in the way of Treasury bills and Treasury bonds enormous emissions [24]. Lately, these hundred millions of Georgian state securities papers were purchased by the commercial banks in Georgia (as the alone dealers on the market) and used as collaterals (with the number of other securities and instruments) to get back millions of loans in Georgian Lari from the National Bank of Georgia via refinancing loans and Auctions [24]. Such "gambling with money" was accompanied by decline of treasury account balance starting the end of 2013. To make things worsening, the National Bank adopted a number of regulations on Microfinance Organizations (MFIs) in the way of "tightening currency policy" [25]. It included obstacles for MFIs to have deposits at commercial banks, tightening reserve requirements and other procedures-resulted massive foreign currency outflow from finance system in Georgia. Only in late November, 2015, Government of Georgia and the National Bank of Georgia have started the process of stabilization-refinancing loans were limited from 1.3 billion Gel to 750 million Gel and lately to 250 million Gel. Growth in Treasury securities emissions was limited at the range of 1.7 - 1.8 billion Gel. That resulted Georgian Lari monetary aggregate (M2, M1 and M0) stabilization and exchange rate appreciated from 2.49 to 2.12 Gel per 1 USD in May 2016 [1] [26] [27].

\section{Georgian Currency: Recent Situation and Development Scenarios}

We have studied the mechanism of internal debt growth and its influence on currency devaluation. In the last three years emission of State Securities papers has increased dramatically [25] [28]:

In October 2012-702 million Georgian lariinternal Debt;

In December 2013-864 million Georgian lariinternal Debt;

December 2014-1.457 million Georgian lariinternal Debt;

October 2015-1.824 million Georgian lariinternal Debt;

January 2016-1.797 million Georgian lariinternal Debt;

August 2016-2.072 million Gel.

It should be noticed one peculiarity-as a rule, the emission of the state securities results the strengthening of the exchange rate, but not in Georgian reality. State Security papers were used by commercial banks as collateral to receive loans from the National Bank of Georgia and converted sums into US Dollars. As a result, the Georgian Lari circulation has increased drastically and that was one of the main reasons for the currency devaluation [29]. 
Also, GEL exchange rate was negatively affected by non coordinate activity between Ministry of Finance of Georgia and the National Bank of Georgia. For example, at the end of 2015, there were 900 million GEL on Treasury balance, but in early 2016 it was just 622 million Gel and in February the remainder was just 300 million Gel-this issue also affected Georgian Lari exchange rate against USD on the local market. It just increased M0 aggregate and stimulate population who lost trust in local currency to convert its saving into USD [30].

From the other point of view, it was positive for Georgian economy, that energy prices drop dramatically as Georgia is an energy imported country and this issue helped Lari rate-reduced the payments for imported energy (mainly in US dollars). But it was a pretty heavy blow for Georgia's energy future projects, as such drop dramatically reduced their investment attraction and several companies cancelled the investment memorandum [31].

Another source of worry is the foreign debt issue of Georgia. For now it is in the range of 14.5 billion USD, close to 100 percent of GDP. Most of debts are private credit line, borrowed by local commercial banks in US dollar denominated short-term and costly resources (10 - 15 times more expensive, compare to the European markets rates). These loans are issued to public and to companies in USD (around 8 billion USD) and payments should be done according to the actual exchange rate of USD to Gel. Due to Lari devaluation, costs of debts increased enormously and stimulated dollarization of Georgian economy (up 80 percent) [13].

In April 2016, Georgian Government and the National Bank of Georgia announced program of Larization of economy (stimulation of local currency and some measures to decrease dependence on USD) [28]. Obligatory reserves were changed, cost of refinancing loans was reduced, but it resulted once more Lari exchange rate depreciation against USD. Gel exchange rate plummeted from 2.12 to 2.31 per 1 USD. Such dramatic depreciation was not result just the policy of Larization, but currency intervention: NBG purcshased up $300 \mathrm{mln}$ USD from the market and thus, once more increased Gel monetary aggregates in economy. As of September 2016:

- monetary aggregate M2 reached 6.150 million Gel, instead of 5.350 million Gel as of February, 2016 ( increased by 800 million Gel);

- foreign currency flow at banking channels was equal to 3.365 million USD (actual exchange rate 2.3 Gel per 1 USD), instead of 3.150 million USD as of February 2016 (exchange rate 2.47 Gel per 1 USD) (increased by 215 million USD);

- Monetary aggregate M0 reached 2.782 million Gel, instead of 2.274 million Gel as of February 2016 (increased by 500 million Gel).

As we see, in March-April 2016, just stabilized Lari exchange rate was again tested by unclear political will and as for September 2016 we have monetary aggregate (M0) increased by more than 500 million Gel, at the same time M2 was increased by 800 million Gel and just 215 million USD inflow of foreign currency was fixed at banking channels. Not surprisingly, Lari exchange rate depreciated against USD and now it is trading at the range of $2.25-2.31$. Georgian government announced its target average 
exchange rate for 2014 as $1 \mathrm{USD}=2.40 \mathrm{Gel}$. More interesting is position of the National Bank of Georgia. It's vice-president announced that exchange rate of 2.10-2.15 Gel per 1 USD is too high and it will act again (buy US dollars and increased Gel monetary aggregates in economy) if it happens. But, 2.5 Gel per 1 USD is too low and it will act vice versa (sell US Dollars and decreased Gel monetary aggregates in economy) if it happens [19].

In line with Larization process, Georgian Government asked business and population not to buy foreign currency if there is no need in it to prevent panic and speculation. We have studied Georgian Government (19 members) and Georgian Parliament (150 member) publicly available declaration in the field of confidence to Georgian lari from decision makers. The figures are the following (as of August 2016) [32] [33]:

- Georgian Parliament members (150 members) keep money in the following structure-2.443.901 USD, 782.758 EURO, 166.053 GBP and 5.274.895 Gel. They have loans-14.216.583 USD, 391.596 EURO and 1.468.539 Gel;

- Georgian Government members (19 members) keep money in the following structure-5.153.035 USD, 4.934.953 EURO and just 382.743 GEL. Regarding loans4.169.940 USD, 463.500 EURO and 454.234 GEL.

- We have fixed foreign currency increase in portfolio of the several ministers and member of Parliament in the period of 2014-2016.

It is logical, that after such "monetary policy" and figures Georgian public and business lost its confidence to Lari and Lari itself lost its main function-saving one. In our opinion, it is obligatory to stabilize Lari rate and to return the confidence to currency.

\section{Conclusions}

As a conclusion, we can state that Lari has actually lost at least one function-the accumulation of resources and it is sharply limited its exchange and measure of value functions.

The main goal of monetary policy of the sovereign country is to maintain its political and economic independence. In this regard, the cornerstone of any economic policy should be to reach stable economic growth and welfare of the population that will ensure the steady and reliable integration into the world community as a successful, progress and innovation-based state. The economy and its main indicator-the monetary system-are necessary for such a solid and predictable environment, which would be a reliable basis for further progress and development.

This model is called a strong asymmetry in financial society. This is a model of the financial system where information from the past and present is available. It has a transparent and reliable statistics based on the environment and the most importantly, there is an opportunity to plan the future, its expected financial strategy, course and outcome [1].

Unfortunately, in Georgia we can observe the low level of financial and economic asymmetry, or in other words, the only one we have to study is the ability to analyze the past. The current situation in finance and economy shows non-transparent market 
conditions, subjectivity and emotional rule of management in economy, absence of developed financial and capital markets (and its actual liquidation). Such conditions do not allow us to analyze the current situation, which is totally groundless deprives future forecasts and their possible reflection model. This removes the basis for any attempt to establish real stability and ensure sustainable future-oriented, long-term and stable development of the financial strategy.

Growing negative balance of payments was 5.5 billion US dollars in 2015 and is widening in 2016, which shows a negative pressure on Lari rate too, because there is a decrease in foreign exchange currency inflow. Such conditions create instability to exchange rate and add additional problems to the monetary policy. The only way to improve the situation is the solid and reliable economic growth, although the rate of growth was too low: in January-June 2016, just 2.8 percent of growth per year, similar to 2.5 growth rate fixed in 2015. Overall, the business environment in Georgia is not reliable one to support sustainable growth. As of February 2016, commercial banks in Georgia issued credits of 16.2 billion Gel, while in collateral portfolio banks fixed more than 300 billion Gel property [32]. Such unprecedented proportion (1 to 20) compared to developed countries and to international practice (usual proportion should be 1 to 2 , or 1 to 3 in developing countries) does not support business to develop its business and activity [32]. In such situation, the whole business in Georgia is actually in collateral of commercial banks and attracted resources are quite expensive (15 - 20 times more expensive in comparison with international practice). In our view, it is impossible to have stable and rapid economic progress and the improvement of the situation based on current conditions.

\section{Acknowledgements}

The authors wish to thank all those whose support had a contribution in the production of this paper. Included in the list of valuable support are Prof. Vladimer Papava, Faculty of Economics and Business of Tbilisi State University, colleagues from Tbilisi State University and Partners from Brokerage company "Georgian Investment Group Plus" LLC.

\section{References}

[1] Aslanishvili, D. and Omadze, K. (2016) Monetary Crises in Georgia: Lessons and Prospects (1995-2016). Scientific Journal “Ekonomisti”, 1, 89-108. (In Georgian) http://ekonomisti.tsu.ge/?cat=nomer\&leng=eng\&adgi=80\&title=MONETARY+CRISES+IN +GEORGIA\%3A+LESSONS+AND+PROSPECTS+\%281995+-+2016\%29

[2] Papava, V. (2005) "Necroeconomics": The Political Economy of Post-Communist Capitalism, iUniverse, Inc., Chapter 9, The Post Communist Georgian Economy, 129-136.

[3] Source: “Georgian Investment Group Plus”. Georgian Currency, Part 1, (1991-1995). http://www.investgroup.ge/padmin/en/research/files/Georgian_Currency_Policy_Review_p art_1.pdf

[4] Source: David ASLANISHVILI “Monetary Policy in Georgia”. Scientific Seminar, Political and Economy Discussions with Lado Papava, Tbilisi State University Newspaper. 
http://newspaper.tsu.ge/uploads/newspaper/N-8\%20(2195)-2016.pdf

[5] Source: National Bank of Georgia, Statistical Data. Divisions and Statistics from Broad Money Aggregates, Monetary Statistics, Money Market Indicators. https://www.nbg.gov.ge/index.php?m=304

[6] Source: David Aslanishvili. Channel “Georgian Arxi”, "Financial Advisor”. Georgian Currency (Coupon and Lari) and Its History 1993-2015.

https://www.youtube.com/watch?v=uiKgVd5vmvk

[7] Source: “Georgian Investment Group Plus”. Georgian Currency, Part 2, (1995-1999). http://www.investgroup.ge/padmin/en/research/files/Georgian_Currency_Policy_Review_p art_2.pdf

[8] Source: David Aslanishvili. Lari Rate Depreciation and Possible Results. https://www.youtube.com/watch?v=j2xmlES7LII\&list=UUY3gxPHnAvcLGMi6Q2XvTeg

[9] Source: “Georgian Investment Group Plus”. Georgian Currency, Part 3, (1999-2003). http://www.investgroup.ge/padmin/en/research/files/Georgian_Currency_Policy_Review_p art_3.pdf

[10] Source: “Georgian Investment Group Plus”. Georgian Currency, Part 4, (2003-2008). http://www.investgroup.ge/padmin/ge/research/files/Georgian_Currency_Market_Review_ _part_4_.pdf

[11] Papava, V. (2015) Georgian Economy: Reforms and Pseudoreforms. Tbilisi, 145-146.

[12] Aslanishvili, D. (2015) Georgian Eurobond: Unknown Reasons of Issue. Proceedings of Materials of International Scientific-Practical Conference "Actual Problems of Sustainable Development of National Economies”, Tbilisi, 10-11 July 2015. http://pgie.tsu.ge/contentimage/konferenciebi/2015_.pdf

[13] Kovzanadze, I. (2016) Lessons from the World Economic Crisis and Formation of the New Development Model. Tbilisi, 224.

[14] Papava, V. (2015) Georgian Economy: Reforms and Pseudoreforms. Tbilisi, 146-148.

[15] Source: Lado Papava "What Are the Threats of the M3 Decreasing? Interview to the "Alia", 25-26 December 2008. (In Georgian) http://papava.info/publications/fulis_masis_zrda.pdf

[16] Papava, L. (2008) \$250 mln Was Spent with No Positive Results-Interview to the "Versia". Source. (In Georgian) http://papava.info/publications/250_milioni_tranSi.pdf

[17] Papava, L. (2008) How Much Was Earn by the Officials from the Gamble of the Exchange Rate of the Georgian Lari-Interview to the "Alia". Source. (In Georgian) http://papava.info/publications/ramdeni_milioni_iSoves.pdf

[18] Aslanishvili, D. (2016) Rustavi 2 Channel, Business Courier-Lari Exchange Rate and Risk Factors. Source. http://www.myvideo.ge/tv/rustavi2hqnew\&seekTime=16-01-2016\%2013:33

[19] Aslanishvili, D. (2015) Lari Forecast-Interview to “Rezonance”. Source. http://resonancedaily.com/index.php?id_rub=3\&id_artc=27226

[20] Aslanishvili, D. (2016) TV Iberia, Busines Code-Lari Exchange Rate and Forecast, Source. https://www.youtube.com/watch?v=Npvpaf5362E \&feature=share

[21] Aslanishvili, D. (2016) Interview on Reasons of Lari Depreciation. Source. http://for.ge/view.php?for_id=44851\&cat=1

[22] Aslanishvili, D. (2016) Palitra TV-Trend of Lari. Source. http://www.palitratv.ge/palitranewsekonomika/74687-rodis-dastabilureba-laris-kursi-eqspe rtebi-gamyarebis-tendenciis-shemdeg-laris-stsraf-gaufasurebas-afaseben.html

[23] Papava, V. (2015) Georgian Economy: Reforms and Pseudoreforms. Chapter on Donor As- 
sistance in 2008 and Lari Rate Fluctuations, Tbilisi, 146-148.

[24] Aslanishvili, D. (2015) Georgian State Security Papers. Tbilisi, 134. (on Treasury Securities Market Trend)

[25] Aslanishvili, D. (2016) TV Channel "New Georgia“-Lari, Economic Policy, Online Loans, Energy. Source. https://www.youtube.com/watch?v=NQZG-TmPJuo

[26] Aslanishvili, D. (2016) Channe TV 1. Georgian Lari and Economic Situation in Georgia-Debates. Source. https://www.youtube.com/watch?v=tuuhZ_vTKRA

[27] Aslanishvili, D. (2016) Interview on Larization Policy of the National Bank of Georgia. Source. http://for.ge/view.php?for_id=45317\&cat=3

[28] Aslanishvili, D. (2015) Rustavi 2 Channel. Business Courier-Future of Georgian Lari and Monetary Policy. Source. http://www.myvideo.ge/tv/rustavi2hqnew\&seekTime=26-09-2015\%2013:08

[29] Aslanishvili, D. (2016) First Channel-Lari Exchange Rate and Its Forecast. Source. https://www.youtube.com/watch?v=eH4B64crFHQ\&feature=youtu.be

[30] Aslanishvili, D. (2016) Rustavi 2 Channel-Lari Rate. Source. http://rustavi2.com/ka/video/12449?v=2

[31] Aslanishvili, D. (2016) Interview to the "Iverioni" on Lari Exchange Rate. Source. http://iverioni.com.ge/15772-davith-aslanishvili-isethi-shthabetcdileba-iqmneba-thithqos$\underline{\text { mthavrobac-da-erovnuli-bankic-laris-kursis-tsinaaghmdeg-moqmedeben.html }}$

[32] Aslanishvili, D. (2016) Interview to the "BPN Agency" on Larization and What Do Currency Prefer Georgian Parliament and Government Members Itself? Source. http://www.bpn.ge/finansebi/26030-ra-valutashi-inakhaven-fuls-parlamentarebi-da-mthavr obis-tsevrebi.html?lang=ka-GE

[33] Aslanishvili, D. (2016) Interview to the "Commersant"-The Structure of Georgian Parliament and Government Members Deposits and Currency Issue. Source.

http://www.commersant.ge/?m=5\&news_id=40736\&cat_id $=8$

\section{Submit or recommend next manuscript to SCIRP and we will provide best service for you:}

Accepting pre-submission inquiries through Email, Facebook, LinkedIn, Twitter, etc.

A wide selection of journals (inclusive of 9 subjects, more than 200 journals)

Providing 24-hour high-quality service

User-friendly online submission system

Fair and swift peer-review system

Efficient typesetting and proofreading procedure

Display of the result of downloads and visits, as well as the number of cited articles

Maximum dissemination of your research work

Submit your manuscript at: http://papersubmission.scirp.org/

Or contact me@scirp.org 